\title{
Pendidikan Madrasah di Indonesia dalam Potret Waktu: Studi atas Sejarah Perkembangan Madrasah di Indonesia
}

\author{
Abdul Kirom ${ }^{1}$, Imroatul Imamiyah ${ }^{2}$ \\ ${ }^{1}$ Pascasarjana UIN Maulana Malik Ibrohim Malang, Indonesia \\ ${ }^{2}$ Pascasarjana Institut Agama Islam Negeri Madura, Indonesia \\ ${ }^{1}$ kiromhafi@gmail.com, ${ }^{2}$ imroatulimamiyahafi@gmail.com
}

\begin{abstract}
Abstrak
Dahulunya madrasah hanya berbentuk majelis-majelis Rasulullah yang berpusat di kota Mekah, baik bertempat di masjid-masjid atau di rumah beberapa sahabat. Disebut madrasah dikarenakan madrasah adalah sekolah atau perguruan yang berdasarkan agama Islam. Madrasah-madrasah yang masuk ke Indonesia pada masa penjajahan Hindia-Belanda adalah madrasah berbentuk pesantren, sebab pesantren di Indonesia adalah lembaga perguruan yang mengajarkan agama Islam, yang mana hal itu merupakan jelmaan dari majelis Rasulullah di Mekah. Seiring berjalannya waktu, madrasah (di Indonesia yang merupakan pesantren saat itu) dituntut untuk diformalkan dalam satuan sistem kurikulumnya oleh pemerintah negara. Oleh karenanya, kini lambat-laun, setelah berkali-kali dituntut untuk bergerak ke arah formal, dikenal bentuk madrasah dari tingkat RA, MI, MTs., MA dan MAK. Semuanya kebanyakan masih bernaung di bawah pesantren sebab makna awal pesantren adalah cerminan dari cikal-bakal madrasah, yang keduanya sampai hari ini masih sulit untuk dipisahkan satu dengan yang lainnya.
\end{abstract}

Kata Kunci: madrasah, pesantren, sejarah

Abstract 
Previously, madrasas were only in the form of assemblies of the Prophet centered in the city of Mecca, either in mosques or at the homes of several friends. Called madrasas because madrasas are schools or colleges based on Islam. Madrasas that entered Indonesia during the Dutch East Indies colonial period were madrasas in the form of pesantren, because Islamic boarding schools in Indonesia were educational institutions that taught Islam, which was the incarnation of the Prophet's assembly in Mecca. Over time, madrasas (in Indonesia, which were pesantren at that time) were required to be formalized in the unit curriculum system by the state government. Therefore, now gradually, after being repeatedly demanded to move in a formal direction, madrasas are known from the RA, MI, MTs., MA and MAK levels. Most of them are still under the auspices of pesantren because the original meaning of pesantren is a reflection of the forerunner of madrasas, the two of which are still difficult to separate from one another to this day.

Keywords: history, madrasah, pesantren

\section{PENDAHULUAN}

Makna madrasah berdasarkan kamus besar bahasa Indonesia (KBBI) adalah "sekolah atau perguruan, yang biasanya berdasarkan agama Islam". ${ }^{1}$ Sementara itu, istilah madrasah diambil dari akar kata atau derivasi dalam bahasa Arab darasa-yadrusu-darasan yang jika diterjemahkan dalam bahasa Indonesia memiliki makna "belajar". 2 Madrasah merupakan Isim makan sehingga memiliki arti "tempat belajar", yang mana padanan kata madrasah dalam bahasa Indonesia adalah sekolah. ${ }^{3}$

Maksum dalam bukunya yang berjudul madrasah sejarah dan perkembangannya memaparkan bahwa madrasah adalah nama atas suatu wadah atau lembaga yang di dalamnya terdapat proses

\footnotetext{
${ }^{1}$ KBBI Online, “Arti Kata Madrasah.” diakses pada 24 April 2020.

2 Supani, "Sejarah Perkembangan Madrasah di Indonesia," Jurnal Pemikiran AlTernatif Pendidikan Insania, vol.14, no. 3 (September 2009), 2.

${ }^{3}$ Ahmad Warson Munawwir, Kamus Al-Munawwir, t.t., 398.
} 
transmisi ilmu pengetahuan yang mengalami perkembangan dari pendidikan Islam non formal sampai menjadi pendidikan formal. ${ }^{4}$

Madrasah merupakan lembaga pendidikan yang dihasilkan oleh dinamika perkembangan masjid, masjid khan (masjid berasrama) yang semula-mula adalah tempat belajar bersifat informal, namun kemudian berubah bentuk menjadi pembelajaran formal, yakni madrasah, yang tujuan akhirnya mampu menopang peradaban hingga disegani dunia. ${ }^{5}$ George Makdisi memaparkan sejarah madrasah diklasifikasikan dalam tiga tahap yakni masjid kemudian masjid Khan (asrama) dan terakhir madrasah. ${ }^{6}$

Seorang ilmuwan bernama Charles Michael Stanton memaparkan dalam bukunya yang berjudul "Higher Learning in Islam: the Classical Period" bahwa terdapat dua corak lembaga pendidikan klasik yang terlahir dari rahim ajaran Islam yakni pendidikan formal dan pendidikan informal. ${ }^{7}$ Dua hal yang dimaksud dalam kata formal dan informal ada pada istilah madrasah, yang berproses dari tempat belajar informal yang semula di masjid-masjid hingga di kelas-kelas dengan diatur kurikulum, yang hari ini kita kenal dengan istilah madrasah.

Istilah satuan pendidikan madrasah yang seringkali kita temui yang digunakan di Indonesia belakangan ini antara lain adalah Raudatul Athfal (RA), Madrasah Ibtidaiah (MI), Madrasah Tsanawiyah (MTs.), Madrasah Aliah (MA), dan Madrasah Aliah

\footnotetext{
${ }^{4}$ Maksum, Madrasah Sejarah dan Perkembangannya (Jakarta: Logos Wacana Ilmu, 1999).

5 Tita Rostitawati, "Transmisi Ilmu dalam Tradisi Islam," TADBIR:Jurnal Manajemen Pendidikan, vol.5, no. 2 (Agustus 2017), 68.

${ }^{6}$ George Makdisi, "The Rise of Colleges" (Intitutions of Learning in Islam and the West, 1981).

7 Charles Michael Stanton, Higher Learning in Islam: the Classical Period (Maryland: Rowman and Littlefield, 1990), 122.
} 
Kejuruan (MAK), kelima istilah RA, MI, MTs., MA dan MAK ini disebut istilah madrasah karena dalam muatan kurikulumnya terdapat pelajaran-pelajaran keislaman. Keseluruhannya, secara sistematis telah disetarakan dengan pendidikan yang bernaung di bawah kemendikbud dan diakui setara dengan TK, SD, SMP, SMA dan SMK. ${ }^{8}$ Namun kemudian story of madrasah di bumi Indonesia menjadi khas dan melekat dengan budaya pesantren yang lahir di tanah Jawa.

Singkat keterangan, istilah madrasah hadir sebagai pengimbang antara pembelajaran ilmu pengetahuan dan agama sekaligus, sebab: Agama tanpa ilmu lumpuh, sedangkan ilmu tanpa agama buta, dengan gambaran tersebut dapat di simpulkan betapa pentingnya korelasi antara agama dan ilmu, karena Madrasah dapat menjembatani hal-hal tersebut yakni agama dan ilmu.

Oleh karena itu, artikel ini akan menguraikan tentang: 1) cikalbakal tumbuhnya madrasah di bumi, 2) sejarah perkembangan madrasah di Indonesia dan 3) Madrasah pada masa revolusi industri 4.0 dan era pandemi covid -19 .

\section{HASIL DAN PEMBAHASAN}

\section{Cikal-Bakal Tumbuhnya Madrasah Di Bumi}

Berbicara terkait cikal-bakal madrasah adalah pembahasan tentang sejarah yang panjang, sebab madrasah hadir semenjak 14 abad silam bersamaan dengan diutusnya baginda Muhammad SAW.

\footnotetext{
${ }^{8}$ Wikipedia Online, "Madrasah" diakses pada 24 April 2020.
} 
diutusnya baginda merupakan awal mula dari cikal-bakal terdapatnya madrasah di atas bumi. Alih-alih hal itu terjadi pada masa bi'thah (masa diutus dan diangkatnya Muhammad bin Abdullah sebagai seorang rasul Allah), persis ketika diturunkannya wahyu berupa seruan إِقَرَأْرَ bacalah" melalui Jibril as atas sang baginda Muhammad.

Disebutkan bahwa dari 'Arsy tertinggi Allah "mentadris atau mengajari” Nabi-Nya Muhammad yang bermukim di bumi pelajaran agama Islam melalui malaikat Jibril. Meski pada awalnya Muhammad Rasulullah merasa tidak mampu untuk menerima pendidikan itu, namun setelah melewati beberapa proses hebat beliau pun mampu mempelajarinya dengan baik. Seruan untuk membaca dengan rangkaian asma Allah dalam agama Islam yang semula diturunkan seakan hendak gagal lantaran baginda Muhammad menurut kisah-kisah mu'tabar (terpercaya), beliau adalah sosok nabi yang tidak bisa membaca dan menulis, dan dalam posisi ini akan nampak tidak mampu menerima pelajaran berupa wahyu yang harus beliau baca, ${ }^{9}$ namun Allah menjamin beliau untuk sekali membaca dengan "takkan pernah lupa selamanya" dalam firmannya “ "سَنْقُرِئُكَ فَفَا تَنْسَنى (kami akan membacakan Al-Qur'an padamu Muhammad maka kamu tidak akan lupa) QS. Al A'laa, $6 .^{10}$

\footnotetext{
${ }^{9}$ Fattah Syamsuddin dan Abdul Kirom, Al-Qur'an wa Al-Hadith li Al-Juz At Thaniy, Al-Qur'an wa Al-Hadith li Al-Juz At Thaniy (Qismu Ta'lim Al-‘Ali Ma'had Tahfidz Al-Qur'an Al-Amien Prenduan, t.t.), 61-62.

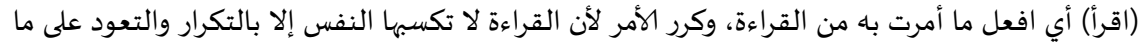

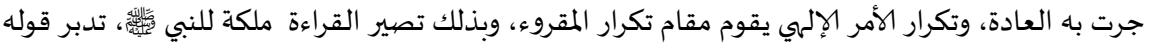

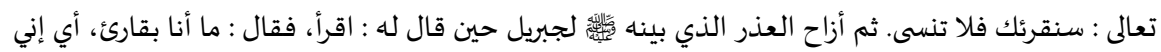

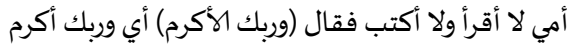


Dalam suatu keterangan tersampaikan bahwa madrasah pertama yang terdapat sepanjang sejarah Islam adalah rumah Abu Abdillah al-Arqam bin Abi Al-Arqam. Dikarenakan di tempat itu lah amal shaleh dan ilmu pengetahuan diajarkan pertama kali oleh sang guru, yang tak lain adalah Muhammad Rasulullah, sementara yang menjadi muridnya adalah para sahabat As-Sabiquna Al-Awwalun. ${ }^{11}$

Sementara dalam keterangan lain, juga terdapat sejarah madrasah yang disebut oleh Dr. Siswanto, salah satu dosen IAIN Madura dalam Jurnal yang ia tulis sebagai institusi lembaga pendidikan par-excellence, terkait dengan siapa yang mempopulerkan madrasah, sejarah yang kedua ini mencatat bahwa madrasah Nidzhomiyah merupakan prototype dalam mempopulerkan madrasah selanjutnya yang dibangun oleh Nizham al-Mulk pada tahun $459 \mathrm{H}$ atau $1067 \mathrm{M}$, meskipun ia bukanlah pencetus pertama dalam pembangunan madrasah, yang pada saat itu Nizham al-Mulk merupakan seorang wazir. ${ }^{12}$

Ahmad Syalaby memaparkan dalam bukunya yang berjudul bahwa Madrasah Nidzomiyah tersebut bertujuan menyebarluaskan ajaran agama Sunni demi menghadapi tantangan Syi'ah dengan cara mempersiapkan tenaga didik pemikiran Sunni serta menyiarkan paham Sunni ke pelosok desa. Dalam bidang pendidikan serta manajemen, mereka membentuk kelompok pemikiran Sunni, guna berpartisipasi dalam lingkaran politik pemerintah. $^{13}$

\footnotetext{
${ }^{11}$ Wikipedia Online, "Madrasah" diakses pada 24 April 2020.

${ }^{12}$ Siswanto, "Kebangkitan Madrasah Dunia Islam,” Tadris, vol.3, no. 1 (2008), 74.

${ }^{13}$ Ahmad Syalabi, at-Tarbiyatu Wa at-Ta'liem Fi alFikri al-Islam, 8 ed. (Maktabah an-Nahdlah al-Misriyah, 1987).
} 
Sederhananya, cikal-bakal madrasah ini kemudian berkembang mengiringi perjalanan mengajar Nabi selama kurang-lebih 23 tahun lamanya, yang mana madrasah tersebut diselenggarakan di masjid ataupun di Kuttab yang selalu menyesuaikan dengan lingkungan yang dinamis sejalan dengan perkembangannya jaman. ${ }^{14}$ Maka kemudian, di dalam madrasah-madrasah itu terdapat nilai-nilai yang diadopsi oleh madrasah berikutnya dari waktu ke waktu, yang antara lain disebutkan dalam artikel yang ditulis oleh Abdul Kirom, sebagaimana berikut:

Pembelajaran bertahap; yang dimaksud dengan pembelajaran bertahap di sini adalah pembelajaran yang dimulai dengan cara memudarkan kemusrikan-kemusrikan yang sedang semarak dilakukan oleh para Arab jahiliyah saat itu, sebagai tujuan awal, kemudian madrasah Nabi datang dengan bertujuan untuk menanamkan Iman ke dalam hati dan otak mereka dalam proses yang terbilang panjang dengan cara perlahan.

Pusat-pusat pengajaran atau adrasah disebut ajelis-majelis Rasulullah; dimulai dari "Dar Al-Islam" awal tempat Islamdisebarluaskan secara sembunyi-sembunyi (begitu juga dengan kegiatan membaca Al-Qur'an), dan pada akhirnya mereka berpusat di Mekkah, kemudian pada saat itu masjid menjadi masyhur sebagai tempat belajar. Itulah majelis-majelis khusus dalam potongan sejarah perjalanan hidup beliau. Namun secara umum, di mana pun dan kapan pun Rasulullah selalu dapat menjawab pertanyaan yang muncul silih berganti dengan artian, di mana-pun beliau berada, di tempat itu juga bisa dijadikan tempat sebagai tempat mendapatkan

\footnotetext{
${ }^{14}$ Goerge Makdisi, The Rise of Humanism in Clasical Islam and the Christian West (London: Edinburgh, 1990).
} 
ilmu (Majelis Ta'lim). Tempat prosesi transmisi dan transfer ilmuilmu keislaman.

Peran pengajaran dan pendidikan; Rasulullah selalu halus, penuh budi dan santun dalam menyiarkan dan menyampaikan risalah, mengulangi berkali-kali keterangannya sehingga yang mendengarkan cepat dan mudah hafal. Rasulullah mentransmisikan Ilmu pengetahuan dengan penuh kasih sayang, sehingga semuanya antusias dan senang untuk belajar dengannya.

Pendidikan yang bervariasi; Rasulullah selalu memberikan senggang waktu untuk berfikir pada para siswanya, sehingga mereka tidak merasa bosan dan tidak juga mengalami dan merasakan bagaimana rasanya mendapatkan siraman rohani yang bertele-tele dan bertubi-tubi, dengan kebijakan yang seperti itulah Rasulullah sangat disenangi dan disukai cara mengajarnya. Hal ini sangat efektif untuk ditiru para pendidik masa kini.

Memberikan contoh praktis; Rasulullah sangat jeli dalam menyampaikan. Beliau selalu menyampaikan wahyu satu persatu. Seperti halnya ketika beliau menyampaikan firman Allah satu demi satu sehingga mudah untuk dipahami, bukan 30 juz secara spontan. Rasulallah juga mengawali madrasahnya melalui orang yang terdekat dengannya, lalu pada masyarakat luas.

Memperhatikan situasi dan kondisi; Rasulullah selalu menyampaikan sesuatu dengan tingkat kadar yang sesuai dengan lawan komunikasinya, sehingga tidak pernah menyebabkan salah paham atas apa yang beliau sampaikan.

Memudahkan dan tidak memberatkan; dalam setiap mengambil langkah dan keputusan, Rasulullah selalu hadir dengan nada tegas dan mengambil jalan yang paling mudah untuk diterima, beliau juga 
memberikan rukhshah pada yang lemah. inilah jiwa bijak beliau yang selalu terasa sesuai dengan takaran kemampuan para sahabatnya. Sabda beliau pada mereka (إنما بعثتُ ميسرين...الى أخره)

Pengajaran bagi wanita; Rasulullah membuka madrasah bagi kaum wanita di saat para wanita mengeluh dan mengadu karena mereka (kaum wanita) tidak dapat mengikuti madrasah yang hanya dikhususkan untuk kaum lelaki, dengan seperti itulah para kaum hawa dapat memahami jalan yang terang, pertanyaan serta persoalan yang berkelindan dalam hati para wanita dapat dijawab secara langsung oleh Rasulullah dalam majelis Khusus ini. ${ }^{15}$

\section{Sejarah Perkembangan Madrasah di Indonesia}

Setelah mengetahui cikal bakal tumbuhnya madrasah di bumi, selanjutnya akan dipaparkan sejarah perkembangan madrasah di Indonesia, yang menurut Maksum di latarbelakangi oleh dua hal yakni gerakan pembaharuan Islam Indonesia serta pemikiran para tokoh-tokoh pembaharu seperti Jamaluddin Al-Ghani dan Muhammad Abduh, yang terlihat pada banyaknya mahasiswa yang belajar ke Kairo, Al-Azhar. Dua Respon terhadap pendidikan yang diterapkan oleh Hindia Belanda yang diskriminasi terhadap rakyat Indonesia dalam ranah pendidikan, khususnya pendidikan agama Islam. Berlandaskan alasan tersebut para tokoh berinisiatif mendirikan madrasah sebagai wadah atau lembaga pendidikan untuk rakyat. $^{16}$

\footnotetext{
15 Abdul Kirom, Madrasah Rasulullah (Madura: Institut Dirosat Islamiyah AlAmien (IDIA) Prenduan, 2014), 3-5.

${ }^{16}$ Maksum, Madrasah Sejarah dan Perkembangannya (Jakarta: Logos Wacana Ilmu, 1999).
} 
Sedangkan periodisasi madrasah di Indonesia dapat di bagi dalam tiga fase, yang mana fase pertama bermula sejak awal masuknya Islam ke Indonesia sampai jaman pembaharuan Indonesia, fase kedua pada masa pembaharuan pendidikan Islam seperti halnya Harun Nasution, sedangkan fase yang ketiga, sejak keluarnya UUD Sistem Pendidikan Nasional ( UU No.2 Tahun 1989 kemudian UU No.20 Tahun 2003). ${ }^{17}$

Fase pertama, sebagaimana yang dikabarkan dalam koran harian Republika Jakarta, edisi selasa, 11 Oktober 2005 Ajip Rosidi seorang budyawan, menuliskan dengan baik tentang pesantren dan madrasah, mulai dari sudut asal mulanya, perjalanan perubahan status nilai yang melekat pada penamaannya, hingga pada pesantren yang kita kenali saat ini, dengan judul: "Kembalikan Fitrah Pesantren". ${ }^{18}$

Sebagai bentuk review yang beliau tuliskan. Singkat kata, Rosyadi menuliskan bahwa pesantren seringkali dilecehkan dalam roman-roman pustaka tahun 1920-an. Bahkan, sampai masa 1930-an citra pesantren bagi "orang sekolahan" selalu negatif. Sedangkan di sisi lain, Sultan Takdir Alisjahbana menentang dengan keras pesantren dan kiyainya yang katanya tidak mampu apa-apa untuk melawan penjajah asing. Padahal pada masa itu Dr. Soetomo mengajukan agar madrasah dijadikan lembaga alternatif Indonesia. Namun setelah melihat perbedaan persepsi yang sangat menjurang antara dirinya dengan Sultan Takdir Alisjahbana, Dr. Soetomo memutuskan untuk tidak melanjutkan niatnya sebab polemik tersebut.

\footnotetext{
${ }^{17}$ Nur Ahid, "Madrasah Sebagai Institusi Pendidikan: Sejarah Pertumbuhan dan Perkembangannya," Jurnal Tribakti, vol.19, no. 2 (1 Juli 2008), 12.

18 Ajip Rosidi, "Kembalikan Fitrah Pesantren," Harian REPUBLIKA Jakarta, Selasa, 11 Oktober 2005, www.republika.co.id.
} 
Apalagi para penulis buku balai pustaka yang terdapat pada masa itu memegang kendali penuh media dan menyampaikan bahwa orang-orang lulusan madrasah selamanya tidak akan mendapatkan kemajuan. Sebab hidup yang maju ditandai dengan seberapa tinggi pangkat yang diraih. Sementara itu, para lulusan madrasah hampir pasti tidak ada yang memiliki jabatan berpangkat dalam urusan apapun pada kursi kepangkatan masa Hindia-Belanda.

Semenjak masa pra kemerdekaan bahkan sampai kini, madrasah umumnya banyak terdapat di pedalaman desa-desa di sepanjang Indonesia. Pemerintahan Hidia-Belanda kala itu selalu menaruh rasa curiga pada madrasah yang konon gurunya selalu menjadi sumber pemberontakan terhadap para penjajah. Atas rasa curiga tersebut pertumbuhan jumlah madrasah semakin dihambat dan dipersusah.

Pada masa-masa itu masyarakat keluar masuk madrasah dengan sesuka hati sesuai minat ilmu yang mereka inginkan. Urusan mencari ilmu di madrasah hampir sama sekali tidak berkaitan dengan kepentingan mencari nafkah duniawi, semisal mencari pekerjaan. Tidak ada madrasah yang mengeluarkan ijazah. Madrasah adalah tempat terhormat dalam menuntut ilmu-ilmu agama sesuai keahlian kiyai yang memimpinnya. Alhasil, kegiatan mengantri murni hanya untuk memenuhi hasrat mencari ilmu tanpa iming-iming apapun.

Kamudian, setelah beberapa saat dibacakannya teks proklamasi kemerdekaan, perintah RI melalui Departen Agama memprogramkan berdirinya madrasah-madrasah dengan basis kurikulum terpadu antara ilmu-ilmu agama dan ilmu umum, dengan tujuan untuk memberikan fasilitas pada anak-anak bangsa yang ingin belajar agama tanpa harus berangkat ke pesantren. 
Seiring berjalannya waktu, para santri mulai memiliki keinginan untuk melanjutkan menuntut ilmunya di perguruan tinggi. Padahal untuk sampai pada tujuan itu hanya dapat ditempuh dengan memiliki ijazah SMA. Akhirnya kebutuhan tersebut menjadi tuntutan bagi mereka untuk mengikuti ujian paket dalam mendapatkan ijazah yang setara dengan SMA. Angka statistik menunjukkan bahwa banyak santri yang mampu menjawab ujian kesetaraan SMA dengan baik, hal itu menjadi bukti bahwa kemampuan santri yang sekolah di madrasah (MA) tidak lebih buruk dari pada mereka yang sekolah di SMA.

Terlihat pada masa Orde Baru, pemerintah mengeluarkan sebuah kebijakan atau keputusan untuk memasukkan ilmu-ilmu umum ke dalam kurikulum pesantren. Menurut Ajib Rosidi hal tersebut hanya mengusik-ngusik sistem ngaji yang terdapat di dalamnya. Keputusan itu dikeluarkan memalui SKB tiga menteri (Mentri Agama, Mentri P dan K, dan Mentri Dalam Negeri) dengan salah satu tujuan yang terbaca dalam kacamata budayawan ini sebagai bentuk wujud menghalang-halangi para lulusan pesantren yang hendak masuk ke Universitas Umum jika tidak ikut aturan menteri, bahkan di sisi yang lain terdapat keputusan bahwa hanya yang sekolah di SMA selama tiga tahun yang boleh mengikuti ujian kelulusan SMA pada SKB yang sama, dengan begitu pondok pesantren yang santrinya ingin melanjutkan sekolah di tingkat tinggi hanya memiliki dua pilihan, antara bertahan dengan sistem yang sudah dibangun sendiri dan menjadi ciri khasnya atau ikut keputusan hasil SBK yang diputuskan oleh pemerintah. Sebab kesempatan bagi santri pesantren yang ingin mengikuti ujian akhir SMA sudah ditutup rapat-rapat. 
Dengan demikian, hanya Gontor, Sidogiri dan bebrapa pondok lainnya yang jelas-jelas tidak terkontaminasi oleh putusan pemerintah prihal SBK sebab Gontor sudah mampu untuk menembus Universitas-universitas Timur Tengah dengan mudah, meski pada saat yang bersamaan kebijakan SBK yang dikeluarkan pemerintah telah merubah sistem mayoritas pendidikan pesantren dari yang semula tidak mengeluarkan ijazah sampai mengeluarkan ijazah.

Hingga kini, madrasah dalam standar pendidikannya sudah banyak yang satu haluan dengan pendidikan pada umumnya. Apabila pada zaman dulu orang belajar di madrasah sebatas untuk mencari ilmu, sekarang justru ada dua tujuan dalam belajar, yakni mencerdaskan akal sesuai standar nasional dan mencerdaskan hati sesuai tuntunan agama.

Fase kedua, merupakan fase dimana para ilmuwan mengupayakan pembaharuan dengan cara menyelenggarakan pendidikan Islamyang inovatif, yakni dengan mendirikan lembaga pendidikan dengan mengajarkan para siswanya ilmu pengetahuan agama sekaligus pengetahuan umum, atau dengan memberikan pembelajaran agama kedalam sekolah umum (sekolah yang didirikan Belanda).

Pembaharuan atau modernisasi merupakan pergeseran attitude dan mentalitas sebagai warga untuk dapat menyelaraskan dengan kebutuhan hidup saat ini, jadi pembaharuan pendidikan Islam adalah proses dimana pendidikan Islam menyesuaikan dengan kemajuan jaman serta upaya untuk mentransformasi dan mereformasi 
pendidikan keislaman namun tetap berpijak pada Al-Qur'an dan Hadist sebagai sumber tertinggi dalam ilmu pengetahuan. ${ }^{19}$

Fase ketiga, Undang-Undang Sistem Pendidikan Nasional No.2 Tahun 1989 berbunyi " Pendidikan nasional bertujuan mencerdaskan kehidupan bangsa dan mengembangkan manusia Indonesia seutuhnya, yaitu manusia yang beriman dan bertakwa kepada tuhan yang maha Esa dan berbudi pekerti luhur, memiliki pengetahuan dan keterampilan, kesehatan jasmani dan rohani, kepribadian dan mandiri serta bertanggung jawab pada kemasyarakatan dan kebangsaan”.

Dalam penyelenggaraan pembangunan dan fasilitas, pemerintah pusat dan pemerintah daerah sesuai dengan kewenangannya dapat memfasilitasi pondok atau asrama pesantren untuk memenuhi aspek daya tampung, kenyamana, kebersihan, kesehatan dan keamanan. Sedangkan pada pasal ke 12 no. 2 berbunyi bahwa pemerintah pusat dan pemerintah daerah sesuai dengan kewenangannya dapat memfasilitasi masjid atau madrasah untuk memenuhi aspek daya tampung, kenyamanan, kebersihan, kesehatan, dan keamanan.

\section{Madrasah pada Masa Revolusi Industri 4.0 dan Era Pandemi} Covid-19

Masa revolusi 4.0 atau sering kita kenal dengan kaum Milenium yang ditandai oleh derasnya arus informasi yang menyeluruh keseluruh seantera alam mengakibatkan masyarakatnya mengalami gelombang globalisasi yang sangat pesat. Globalisasi tersebut menjadi tantangan sekaligus ancaman bagi umat Muslim umumnya, bagaimana lembaga pendidikan Islam mengantisipasi arus

\footnotetext{
19 Mulyanto dkk., "Modernisasi Madrasah Awal Abad XIX: Studi Analisis Madrasah Mambaul Ulum Surakarta 1905-1945," Edukasi Islami, vol.08, no. 02 (Agustus 2019), 374.
} 
global tersebut agar tidak menghancurkan sendi-sendi keislaman umat Muslim.

Madrasah saat ini sering menjadi wacana dalam perbincangan public, karena kredibilitas dan kapabilitasnya yang modern. Didik Juhaedi memaparkan, bahwa seorang ahli antropologi Amerika yang menjadi ketua Asosiasi kajian Timur Tengah dan Afrika Utara mengagumi sinergi kebijakan pemerintah dalam melestarikan keberlangsungan madrasah dengan cara menjembatani Ideologi Islam dengan Pancasila dengan cara dikeluarkannya UUD sebagai common platformnya Indonesia. ${ }^{20}$

Adanya madrasah dalam lingkaran pendidikan diharapkan dapat menjembatani umat Muslim agar kembali utuh, memiliki split personality, mempunyai ilmu yang luas, serta berakhlak mulia, serta dapat memadukan sekaligus tiga potensi manusia (IQ, SQ, dan EQ). Sekurang-kurangnya terdapat lima peran yang dapat ditumbuhkembangkan madrasah untuk mencapai tujuan tersebut yakni: ${ }^{21}$

a. Sebagai pendidikan alternatif yang dapat dipilih umat muslim

b. Sebagai benteng moralitas bangsa yang saat ini mengalami kemerosotan moral.

c. Sebagai wadah pembentukan akhlakul karimah umat.

d. Sebagai pemelihara tradisi agama Islam

e. Sebagai media sosialisasi nila-nilai agama Islam

Namun demikian, lantaran wabah yang menyerang pada akhirakhir ini nasib madrasah harus kembali dijalankan sebagaimana awal

\footnotetext{
${ }^{20}$ Didik Juhaedi, “Dinamika Peran Madrasah,” Jurnal Pendidikan dan Studi Islam, vol.1, no. 1 (Desember 2014), 5.

${ }^{21}$ Moh. Toriqul Chaer, "Peran MAdrasah dalam Menghadapi Era Era Globalisasi dan Budaya," MUADDIB, vol.06, no. 02 (Juli 2016), 194.
} 
mulanya "harus belajar di rumah saja", kegiatan madrasah yang sudah berevolusi sangat jauh dari cikal-bakal kelahirannya pertama kali, untuk beberapa waktu ini akan kembali sebagaimana madrasah pada masa Rasulullah, pembelajaran agama Islam hanya akan berlangsung di rumah dan sekitarnya tanpa mengenal jam KBM normal atau formal, semuanya menjadi informal untuk sementara waktu.

Hal tersebut sebagaimana yang telah dilangsir oleh detik news bahwa UNESCO sebagai organisasi pendidikan, keilmuan dan kebudayaan Perserikatan Bangsa-Bangsa (PBB) pada awal maret 2020 menerbitkan data statistic yang sangat tinggi perihal dampak virus corona terhadap dunia pendidikan di kancah internasional. Ada sekitar "300 juta siswa” yang harus di-lockdown dari sekolahnya dan harus belajar di rumah-rumah. ${ }^{22}$

Di antara angka 300 juta itu, berdasarkan permasalahan pendidikan yang juga harus diberhentikan total di Indonesia, terdapat jumlah siswa madrasah sekitar 9.245.248 orang. Sebagaimana data kemenag yang tertera pada pembahasan sub poin sebelumnya.

\section{KESIMPULAN}

Madrasah memiliki makna yang selalu bergerak mengiringi majunya jaman. Dahulunya madrasah hanya berbentuk majelismajelis rasulullah yang berpusat di kota Mekah, baik hal itu di masjid-masjid atau di rumah beberapa sahabat. Demikian disebut madrasah sebab madrasah adalah sekolah atau perguruan. yang biasanya berdasarkan agama Islam.

\footnotetext{
${ }^{22}$ Mohammad Rajab, "Pendidikan di tengah Pusaran Wabah Corona," Detik News, Kamis, 19 Maret 2020, diakses pada 25 April 2020.
} 
Madrasah-madrasah yang masuk ke Indonesia pada masa penjajahan Hindia-Belanda adalah madrasah berbentuk pesantren, sebab pesantren di Indonesia adalah lembaga perguruan yang mengajarkan agama Islam, yang mana hal itu merupakan jelmaan dari majelis rasulullah di Mekah. Seiring berjalannya waktu, madrasah (di Indonesia yang merupakan pesantren saat itu) dituntut untuk diformalkan dalam satuan sistem kurikulumnya oleh pemerintah negara, maka berpijak dari sana, kini lambat laun setelah berkali-kali dituntut untuk bergerak ke arah formal, kita mengenal bentuk-bentuk madrasah bergerak dari tingkat RA, MI, STs., MA dan MAK.

\section{DAFTAR PUSTAKA}

Ahid, Nur. "Madrasah Sebagai Institusi Pendidikan: Sejarah Pertumbuhan dan Perkembangannya.” Jurnal Tribakti, vol.19, no. 2 (1 Juli 2008).

Chaer, Moh. Toriqul. "Peran MAdrasah dalam Menghadapi Era Era Globalisasi dan Budaya." MUADDIB, vol.06, no. 02 (Juli 2016).

Juhaedi, Didik. "Dinamika Peran Madrasah.” Jurnal Pendidikan dan Studi Islam, vol.1, no. 1 (Desember 2014).

Kirom, Abdul. Madrasah Rasulullah. Madura: Institut Dirosat Islamiyah Al-Amien (IDIA) Prenduan, 2014.

Makdisi, George. "The Rise of Colleges." Intitutions of Learning in Islamand the West, 1981.

Makdisi, Goerge. The Rise of Humanism in Clasical Islamand the Christian West. London: Edinburgh, 1990. 
Maksum. Madrasah Sejarah dan Perkembangannya. Jakarta: Logos Wacana Ilmu, 1999.

Mulyanto, Didin Saefudin, Adian Husaini, dan Tiar Anwar Bahtiar. "Modernisasi Madrasah Awal Abad XIX: Studi Analisis Madrasah Mambaul Ulum Surakarta 1905-1945.” Edukasi Islami, vol.08, no. 02 (Agustus 2019).

Munawwir, Ahmad Warson. Kamus Al-Munawwir, t.t.

Online, KBBI. “Arti Kata Madrasah.”

Online, Wikipedia. "Madrasah."

Rajab, Mohammad. "Pendidikan di tengah Pusaran Wabah Corona." Detik News, 19 Maret 2020.

Rosidi, Ajip. "Kembalikan Fitrah Pesantren.” Harian Republika Jakarta, Selasa Oktober 2005. www.republika.co.id.

Rostitawati, Tita. "Transmisi Ilmu Dalam Tradisi Islam." TADBIR : Jurnal Manajemen Pendidikan, vol.5, no. 2 (Agustus 2017).

Siswanto. "Kebangkitan Madrasah Dunia Islam." Tadris, vol.3, no. 1 (2008).

Stanton, Charles Michael. Higher Learning in Islam: the Classical Period. Maryland: Rowman and Littlefield, 1990.

Supani. "Sejarah Perkembangan Madrasah di Indonesia." Jurnal Pemikiran Al-Ternatif Pendidikan Insania, vol.14, no. 3 (September 2009).

Syalabi, Ahmad. at-Tarbiyatu Wa at-Ta'liem Fi alFikri al-Islam. 8 ed. Maktabah an-Nahdlah al-Misriyah, 1987.

Syamsuddin, Fattah, dan Abdul Kirom. Al-Qur'an wa Al-Hadith li Al-Juz At Thaniy. Al-Qur'an wa Al-Hadith li Al-Juz At Thaniy. Qismu Ta'lim Al-'Ali Ma'had Tahfidz Al-Qur'an AlAmien Prenduan, t.t. 
Abdul Kirom, Imroatul Imamiyah | MAHAROT Vol. 5, No. 2, 2021 